\title{
The effect of psyllium on some haematological and biochemical variables in the plasma of horses during an endurance ride: preliminary results
}

\author{
S. Cinotti, C. Guglielmini and A. Boari \\ University of Bologna, Veterinary Clinical Department
}

\begin{abstract}
Die Auswirkungen von Psyllium auf einige hämatologische und biochemische Blutplasmaparameter bei Pferden während eines Distanzrittes: vorläufige Ergebnisse.

Während eines $120 \mathrm{~km}$ langen Distanzrittes wurden bei 8 Pferden verschiedene Blutparameter untersucht. Vor dem Ritt erfolgte eine Einteilung der Pferde in zwei Gruppen, wobei die eine als Versuchs-, die andere als Kontrollgruppe diente. Die 4 Versuchspferde erhielten eine Woche vor dem Ritt täglich Plantago psyllium über das Futter verabreicht. Die tägliche Dosis betrug $0,3 \mathrm{~g} / \mathrm{kg} \mathrm{KGW}$. Die Autoren testeten dieses pflanzliche Präparat, um seine Auswirkungen auf den Hydratationszustand von Pferden während anstrengender Ritte zu testen. Oft erleiden Pferde während eines Distanzwettbewerbs schwere Flüssigkeits- und Elektrolytverluste, da sie stark schwitzen. Der Gastrointestinaltrakt spielt kürzlichen Erkenntnissen zufolge eine wichtige Rolle bei der Rehydratation des Köpers, indem er als immenses Reservoir für die Wasserreabsorption fungieren kann. Das aus der Schote des Ispaghula-Samens gewonnene Psyllium erwies sich bisher als Stuhl-eindickendes und wasserbindendes Mittel, welches sowohl bei Obstipationen als auch paradoxerweise bei Diarrhoe eingesetzt werden kann, da es den Flüssigkeitsverlust im Körper mindert. Die vorliegende Studie dient dem Zweck, die Auswirkungen von Plantago psyllium auf den Dehydratationsgrad von Pferden während eines Langstreckenrittes zu testen. Für das Experiment wurden 8 Araber-Kreuzungen im Alter zwischen 8 und 14 Jahren ausgesucht, denen am Tag des Distanzwettbewerbs in bestimmten Abständen venöses Blut entnommen wurde, und zwar unmittelbar vor Beginn des Rittes sowie nach 40,80 und 120 Kilometern. An diesen Streckenabschnitten fanden auch tierärztliche Kontrollen der teilnehmenden Pferde statt. Neben der Aufzeichnung der Herzfrequenz während des gesamten Rittes mittels eines elektronischen Meßgeräts sollten folgende Blutparameter Aufschluß über den Hydratationszustand der Pferde geben: Hämatokritwert, Serumproteinkonzentration, Natrium-, Kalium- und Chloridgehalt. Alle Pferde erreichten eine Durchschnittsgeschwindigkeit von 13,5 km/h. Die Herzfrequenz der Tiere varriierte zwischen 80 und 160 Schlägen pro Minute. Die Pferde beider Gruppen zeigten keine Unterschiede bezüglich der aufgezeichneten Herzfrequenz-Muster. Der Hämatokritwert stieg bei allen 8 Pferden während des Distanzrittes an, erreichte jedoch bei den Pferden der Kontrollgruppe deutlich höhere Werte. Die Konzentration der gemessenen Elektrolyte veränderte sich bei keinem Pferd während des Rittes signifikant. Dies zeigt, daß alle 8 Pferde eine gute Kondition besaßen und während des Rittes keinerlei Probleme mit Elektrolytimbalancen bekamen. Die Differenz der Hämatokritwerte beider Gruppen könnte auf die wasserbindende Eigenschaft des Psylliums zurückzuführen sein. Plantago psyllium könnte zu einer erhöhten Flüssigkeitsmenge im Darm und somit zu einem geringeren Wasserverlust der Versuchspferde geführt haben. Diese Studie zeigt vorläufig positive Effekte des Psylliums auf das Plasmavolumen von Pferden während anstrengender, langandauernder Beanspruchung. Die Autoren schließen aus ihrem Versuch, daß Psyllium die Leistungsfähigkeit der Pferde während eines Langstreckenrittes verbessen kann. Sie betonen jedoch, daß diese vorläufigen Resultate durch weitere Studien mit größerem Umfang an Pferden überprüft werden sollten.
\end{abstract}

Schlüsselwörter: Pferd, Hämatokrit, Psyllium, Distanzritt, Dehydratation

\section{Summary}

Eight horses were subjected to a 120 kilometer endurance ride. The eight horses were divided into two groups of four horses each. Eight days prior to competition the diet of the experimental group was supplemented daily with Plantago Psyllium at a dose of $0.3 \mathrm{~g} / \mathrm{kg}$ body weight /day. Blood samples were drawn for measuring haematocrit, total serum protein, sodium, potassium and chloride immediately before the start of the race and at the 40,80 and 120 kilometre veterinary check points. In addition, the heart rate of the horses was recorded throughout the whole ride. All horses completed the ride at an average speed of $13.5 \mathrm{~km} / \mathrm{h}$. The heart rate during the ride varied between 80 and 160 beats/min without showing a distinct pattern between the horses of the two groups. The haematocrit increased in both groups during the ride, but to a higher extent in the control group. The concentration of the blood serum variables measured in both groups did not change significantly during the ride. The lower increase of haematocrit in the horses supplemented with Plantago Psyllium may be attributable to a higher water content in their intestine due to its water holding capacity.

keywords: $\quad$ horse, haematocrit, psyllium, endurance, dehydration

\section{Introduction}

During endurance competition horses frequently sustain severe fluid and electrolyte deficits as a result of thermoregulatory fluid losses in sweat and respiratory tract secretion (Rose et al., 1980; Carlson, 1987). The best indicators for the evaluation of hydration state are the measurements of heart rate, temperature, total plasma protein, packed cell volume and plasma electrolytes (Ouragh et al, 1988 ; Sloet van Oldruitenborgh-Oosterbaan et al., 1991). Significant increases in PCV have been attributed both to decreased plasma volumes caused by losses of fluid in the course of 
evaporative cooling and to the mobilization of the splenic erythrocyte reservoir (Carison, 1987). Variable degrees of splenic contraction limit the use of PCV alone in the assessment of dehydration status.

Nevertheless, it is clear that limiting PCV rise during an endurance race could improve body fluid balance and therefore give better opportunities to ameliorate the race performance.

Usually, water is made readily available to the competitors "en route" in order to maintain hydration levels. In addition, given that water accounts for up to $75 \%$ of fecal weight (Naylor et al., 1993), the water content of the gastrointestinal tract is considerable in the horse and could represent a large reservoir for reabsorption during dehydration or prolonged exercise. According to Naylor et al. (1993a) the gastrointestinal tract content most likely plays a significant physiological role regarding interstitial fluid shifts in the horse.

In a previous equine study (Philip, 1993) Psyllium, a soluble fiber derived from the husk of ispaghula seeds, was shown to be a potent stool bulking and water holding agent. By increasing fecal water content, Psyllium mucilloid has historically been used in human and veterinary medicine for the treatment of constipation (Edwards et al., 1992; Fettman, 1992). In what may apppear to be a paradox, this waterholding agent has also been proposed to improve stool consistency in diarrhoic patients (Verschoor and Christensen, 1990 ; Heather et al.,1991; Ehrer et al.,1993). In such cases Psyllium seems to enhance glucose, electrolyte, and water absorption rendering these components more accessible (Fettman, 1992).

The purpose of the study was to determine whether the use of Psyllium in endurance horses can reduce the effects of dehydration during performance.

\section{Materials and methods}

In this study eight healthy Arabian-cross horses (4 mares, 4 geldings), ranging from 8 to 14 years and weighing 390 to $500 \mathrm{Kg}$, were subjected to a 120 kilometer endurance competition. On the basis of success in completion of this ride the best athletes have been selected to join the National Endurance Team. All horses had raced several times within the previous 12 months and their level of fitness was good. The eight horses were assigned to 2 relatively homogeneous groups consisting of four horses divided into an experimental group (A) and a control group (B).

Eight days prior to the competition, the group $A$ diet was supplemented daily with Psyllium (Equisill-Serono) at the dose of $0.3 \mathrm{~g} / \mathrm{Kg}$ body weight $/$ day. ${ }^{*}$

The competition, held in the spring, started on a cool and rainy day (ambient temperature ranging between $11-20^{\circ} \mathrm{C}$ ). Yet, the sun came out later in the morning warming the course which was mostly hilly with soggy terrain.

* Dosage recommended by the Serono Veterinary.
Blood samples were drawn for haematologic and biochemical testing immediatly before the start of the race and at the 40,80 and 120 kilometer veterinary check points. The following parameters were determined: packed cell volume, total serum protein, sodium, potassium and cloride.

The microhaematocrit technique was used for PCV evalua tion, while total plasma protein and plasma electrolytes were determined with an Echo automatic analyzer.

Heart rates during the ride was recorded by using a heart rate meter (Polar Electro OY, Finland).

Rectal temperatures were not measured.

Blood parameters were presented in means \pm SD.

The significance of differences between the two groups was calculated using the $T$ Student's Test. For all analysis, significance was assessed with $p<0.05$.

\section{Results}

All horses successfully completed the ride. The eight horses completed the ride at an average speed of $13.5 \mathrm{~km} / \mathrm{h}$ $(3.7 \mathrm{~m} / \mathrm{s})$.

The heart rate during the ride ranged between 80 and 160 beats $/ \mathrm{min}$. with a relatively comparable distribution in the different rates within the two groups.

The changes in PCV, plasma electrolytes, and total serum protein are shown in Table 1. Both groups started with similar, relatively low PCV values (38\% group B and 39\% group A). The PCV increased progressively in both groups during the ride.

However, the increases were greater in group B (from 38 to $62 \%$ ) compared with those of group A (from 39 to $52 \%$ ). In addition, the difference between the two groups was statistically significant at the 80 and $120 \mathrm{Km}$ check points $(\mathrm{P}<.05)$

The total serum protein during the ride slightly increased in both groups remaining within normal range. The differences between groups regarding this parameter were not significant.

The plasma sodium concentration in group $A$ remained constant throughout the ride. Whereas, the group B mean sodium concentrations showed a moderate decrease at the second and third check points (from 155 to $145 \mathrm{mEq} / \mathrm{l}$ ) and then increased again at the end of the race $(161 \mathrm{mEq} / \mathrm{l})$.

The mean plasma potassium concentration decreased slightly in group A (from 4.0 to $3.3 \mathrm{mEq} / \mathrm{l}$ ) and only in the second and third stages in group $B$ (from 4.0 to $3.8 \mathrm{mEq} / \mathrm{l}$ ). However, the latter group plasma potassium levels increased to reach $4.2 \mathrm{mEq} / \mathrm{l}$ at the fourth check point.

The mean plasma chloride concentration, while remaining within normal range, tended to decrease progressively in group A (from 108 to $92 \mathrm{mEq} / \mathrm{l}$ ) compared with a minimal transient reduction observed in group $\mathrm{B}$ at the second and third check points. In this group, the chloride concentrations returned to the pre-start levels at the end of the competition. Even though all horses completed the ride, on the whole the group A horses tended to qualify better than those of group B. 
Tab. 1: PCV, Serum total protein, Sodium, Kalium, Chloride in psyllium treated horses (group A) and controls (group B): mean values and standard deviations. Different letters in different lines indicate significant differences (Student T test)

\begin{tabular}{|c|c|c|c|c|c|}
\hline & $\begin{array}{l}\operatorname{PCV}(\%) \\
\text { mean }(\mathrm{sd})\end{array}$ & $\begin{array}{l}\text { Serum total } \\
\text { protein }(\mathrm{g} / \mathrm{dl}) \\
\text { mean }(\mathrm{sd})\end{array}$ & $\begin{array}{l}\text { Sodium } \\
(\mathrm{mEq} / \mathrm{l}) \\
\text { mean (sd) }\end{array}$ & $\begin{array}{c}\text { Kalium } \\
(\mathrm{mEq} / \mathrm{l}) \\
\operatorname{mean}(\mathrm{sd})\end{array}$ & $\begin{array}{l}\text { Chloride } \\
(\mathrm{mEq} / \mathrm{l}) \\
\text { mean (sd) }\end{array}$ \\
\hline \multicolumn{6}{|l|}{$\mathrm{km} 0$} \\
\hline Group A & $39.2(7.5)$ & $7.2(0.5)$ & $144.5(5.4)$ & $4.1(0.7)$ & $108.0(4.4)$ \\
\hline Group B & $38.5(4.1)$ & $7.1 \quad(0.3)$ & $155.2(13.2)$ & $4.0(0.4)$ & $112.6(9.5)$ \\
\hline \multicolumn{6}{|l|}{$\mathrm{km} 40$} \\
\hline Group A & $43.2(6.9)$ & $7.8(0.8)$ & $142.8(5.4)$ & $3.6(0.2)$ & $99.7(5.0)$ \\
\hline Group B & $52.2(5.9)$ & $7.5(0.2)$ & $148.5(3.2)$ & $3.8(0.5)$ & 102.5 \\
\hline \multicolumn{6}{|l|}{$\mathrm{km} 80$} \\
\hline Group A & $50.0^{a}(7.0)$ & $8.2(0.7)$ & $145.5(7.5)$ & $3.8(0.6)$ & $98.1(9.1)$ \\
\hline Group B & $61.5^{b}(2.4)$ & $7.9(0.3)$ & $145.2(4.3)$ & $3.8(0.5)$ & $101.0(7.4)$ \\
\hline \multicolumn{6}{|l|}{$\mathrm{km} 120$} \\
\hline Group A & $52.0^{\mathrm{a}}(6.4)$ & $8.3(0.6)$ & $140.0(3.0)$ & $3.4(3.0)$ & $92.3(6.4)$ \\
\hline Group B & $62.5^{b} \quad(2.4)$ & $8.3(0.3)$ & $161.5(26.5)$ & $4.3(0.9)$ & 112.5 \\
\hline
\end{tabular}

\section{Discussion}

The results of this study show that the PCVs in the Psyllium treated horses (group A) remained significantly lower than PCVs of the control horses (group B). Although both groups started the ride with similarly low PCVs, group B showed a $24 \%$ increase in PCV from start to finish. At the same time, total serum protein increased only slightly during the race without significant differences between the 2 groups. The proportionately greater increase in PCV over the total serum protein probably resulted from splenic contraction due to sympathetic stimulation from exercise rather than due to a true dehydration.

All horses maintained heart rates within 160 beats/min with an average heart rate of 120 beats $/ \mathrm{min}$. This data shows that both groups were well trained and worked entirely in aerobic capacity (Persson, 1983).

The fact that there were no significant differences in serum electrolyte concentrations in this study and that all the values remained almost within their normal ranges, it can be assumed that the 2 groups had no serious problems regarding electrolyte balance.

It is well known that the variability of equine PCV appears to be related to the type and intensity of exercise performed, the state of training, acclimatization and the state of hydration of the subject. Nevertheless, the reason why eight welltrained horses competing in a long distance endurance ride, assigned to 2 separated but homogeneous groups showed such different PCV values between the start and the end of the race is not well understood.
The only consistent factor that may have played a role is the presence of the Psyllium added in the group A diet. It has been proposed that the degree of PCV variation may have been a reflection of individual differences in the gastrointestinal fluid volume at the onset of a potential dehydration period (Naylor et al., 1993). In our study, the slight increase of PCV values in Psyllium treated horses may reflect a greater fluid availability deriving from the gut. Other studies have hypothesized that Psyllium may sequester water from liquid stool and /or increase the ratio of fecal solids to fecal water and thereby improve stool consistency. In addition to this, mucilage may either slow gastric emptying and/or modify small intestinal motility giving the intestine a better opportunity to absorb fluid, glucose and electrolytes (Bergman et al., 1992; Fettman, 1992; Cherbut et al., 1994).

Theoretically speaking, if the available fluid volume increases, the effects of dehydration are diminished and, therefore, improving performance during a long distance ride.

In conclusion, this study shows preliminary results on the possible beneficial role of Psyllium to reduce the level of plasma volume dehydration in horses subjected to an endurance competition.

These preliminary results need to be supported by another study in which more horses, and more variables could be measured to elucidate whether Plantago Psyllium could be a useful additive in the diet of horses competing in endurance rides. 


\section{References}

Bergmann J.F., Chassany O., Petit A., Triki R. and Caulin C. (1992): Correlation between echographic gastric emptying and appetite. Gut 33, 1042-1043.

Carlson G.P. (1982): Thermoregulation and fluid balance in the exercising horse. In Equine Exercise Physiology I, eds. Snow D.H., Persson S.G.B. and Rose R.J., pp 291-309

Carlson G.P. (1987): Hematology and body fluids in the equine athlete: a review. In Equine Exercise Physiology II, eds Gillespie J.R. and Robinson N.E., ICEEP Publications Davis CA, pp 393-425.

Cherbut C., Bruley-des-Varennes S., Schnee M., Rival M., Gaimiche J.F. and Delort Laval J. (1994): Involvement of smal! intestinal motility in blood glucose response to dietary fibre in man. Br. J. Nutr. 71, 675-685.

Edwards C.A., Bowen J., Brydon W.G. and Eastwood M.A. (1992): The effects of ispaghula on rat caecal fermentation and stool output. Br.J.Nutr. 68, 473-482

Eherer A.J., Santa-Ana C.A., Porter J. and Fordtran J.S. (1993): Effect of psyllium, calcium polycarbophil, and wheat bran on secretory diarrhea induced by phenolphthalein. Gastroenterology 104, 1007-1012.

Fettman M.J. (1992): Potential benefits of Psyllium mucilloid supple mentation of oral replacement formulas for neonatal calf scours. Comp. Cont. Ed. 14, 247-254.

Heather D.J., Howell L., Montana M. and Howell M, Hill R. (1991): Effect of a bulk-forming cathartic on diarrhea in tube-fed patients. Heart-Lung 20, 409-413.

Naylor J.R.J., Bayly W.M., Schott I H.C., Gollinick P.D. and Hodgson $D . R$. (1993a) : Equine plasma and blood volumes decrease with dehydration but subsequently increase with exercise. J.Appl. Physiol. 75, 1002-1008.

Naylor J.R.J., Bayly W.M., Gollinick P.D., Brengelmann G.L. and Hodgson D.R. (1993b): Effects of dehydration on thermoregulatory responses of horses during low-intensity exercise. J. Appl. Physiol. 75, 994-1001.
Ouragh L.. Constant J.L., de La Farge F., Braun J.P., Rico A.G. and Valdiguie $P$. (1988): Surveillance biochimique de chevaux arabesbarbes pendant le raid "les cavaliers du desert". Revue Med. Vet. $139,907-915$

Persson S.G.B. (1983) : Analysis of fitness and state of training. Evaluation of exercise tolerance and fitness in the performance horse. In Snow, D.H., Persson, S. G.B., and Rose, R.J. (eds) : Equine exercise physiology. Cambridge, England. Granta Editions 441-457

Philip V.P. (1993): Motilita' ed attivita' ciecali nell'equino : osservazioni attraverso fistola e valutazioni laboratoristiche del materiale ciecale normale e patologico. Tesi di Laurea, Università degli Studi di Bologna, Facoltà di Med. Vet..

Rose R.J., Arnold K.S., Church S. and Paris R. (1980): Plasma and sweat electrolyte concentrations in the horse during long distance exercise. Equine Vet. J. 12, 19-22.

Sloet van Oldruitenborgh-Oosterbaan M.M. Wensing T., Barneveld A. and Breuking H.J. (1991) : Heart rate, blood biochemistry and performance of horses competing in a $100 \mathrm{~km}$ endurance ride. Vet. Rec. 181, 175-179.

Verschoor J. and Christensen C.R. (1990): Fluid therapy with specific mucopolysaccharides: a new approach to control diarrhea. Vet. Clin. N. Am. Food Anim. Pract. 6, 69-75.

\section{Dr. Stefano Cinotti}

University of Bologna

Dipartimento Clinico Veterinario

Via Tolara di Sopra 50

Ozzano Emilia 40064

Bologna

Tel. 0039-51-792993

Fax 0039-51-792793

\section{Jetzt zur Saison:}

Unsere

Leistungen für Sie:

Faire Preise

Tierärztliche

Betreuung

Breite Palette an Unter-

suchungen

Schnelle

Befund-

übermittlung
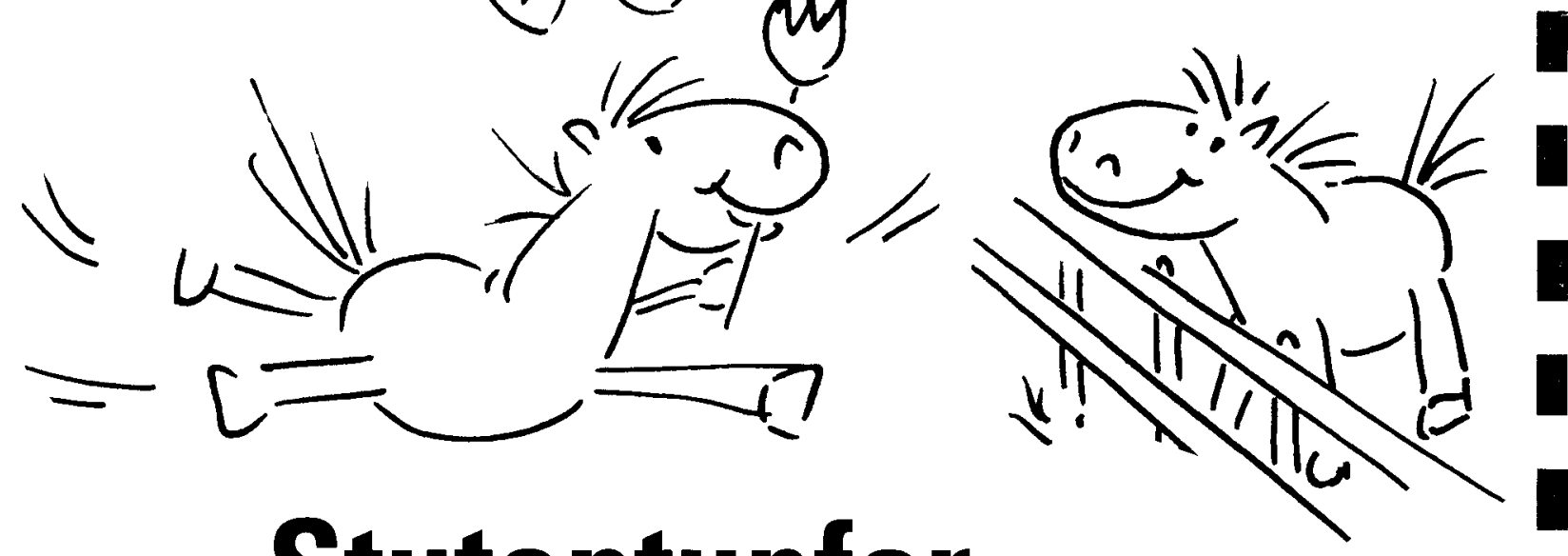

\section{Stutentupfer}

Bakteriologische +
mykologische Untersuchung

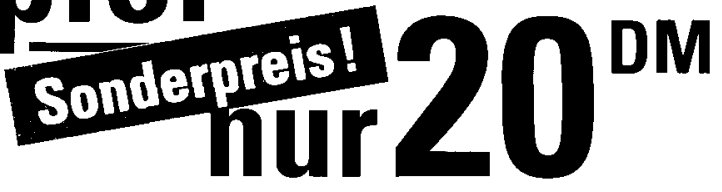

DAS LABOR FÜR TIERÄRZTE 